\title{
The Influence Of Personal Factors On Workers' Turnover Intention In Work Organizations In South-West Nigeria
}

Elsie Omolara Babajide, Olabisi Onabanjo University, Nigeria

\begin{abstract}
This study investigated the influence of personal factors on workers' turnover intention in work organizations in South-West Nigeria. This was for the purpose of ascertaining the relevance of personal variables to turnover intention assessment among industrial workers in Nigeria. The descriptive survey design was adopted for the study. A total of 725 respondents were selected using stratified sampling technique. A set of self developed structured questionnaire titled Personal Factors and Workers' Turnover Intention Scale (PFWTIS) with reliability co-efficient of 0.84 was used for data collection. Multiple Regression Analysis and t-test statistics were used for data analysis at 0.05 alpha levels. The findings revealed that: Personal factors (work-family life, commitment, job satisfaction and general health) significantly influenced workers' turnover intention $F(4,720)=0.570 ; P<0.05)$. Findings revealed that the order of causation in descending order of magnitude: Job satisfaction (Beta $=0.345, P<.0 .05)$; work-family life (Beta $=0.205 ; P<0.05)$, general health $($ Beta $=0.213 ; P<0.05)$ and commitment, $($ Beta $=0.145$; $P<0.05)$. Based on these findings, it was recommended that for retention of workers to be made possible, motivational incentives that could foster workers' job satisfaction and commitment should be provided at equitable measure of reward system to be commensurate with workers` job performance. Also, organizational support system that could promote workers`good health and reduction of occupational hazards should be provided for all levels of workers in order to achieve workers retention.
\end{abstract}

Keywords: Personal factors, workers, turnover intention, South-West, work organizations

\section{INTRODUCTION}

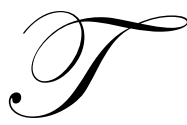

he issue of labour turnover and its attendant problems have received serious attention among the organizational behaviourists. Studies on labour turnover behaviour as it affects job performance effectiveness and organizational productivity in terms of goal achievement has been conducted by various researchers across countries of the world (Akintayo, 2007; Adewoyin 2002, Price, 1992, Richard 2004).

According to Soyibo (2002) and Staw (1980), turnover is the degree of individual movement across the membership boundary of a social system. This definition reveals the dynamic nature of turnover since it shows its concern with movement of worker in and out of organization. This is why Panes (2001) regarded turnover as a process type of concept. This is also why there is need for codifications of the literature concerning employee turnover. By codification, we mean an orderly and compact arrangement of substantive findings or procedures.

The study of turnover cuts across several disciplines.

It was previously noted that economics study turnover under the label of "labour mobility". Turnover is one type of labour mobility - inter-firm movement. Reference is also commonly made to "labour turnover" rather than to "turnover". The label of "labour turnover" is used in this study because it is often interpreted as the turnover of blue-collar workers. There are probably more turnover data about blue-collar workers than about white-collar 
workers. Unskilled, semiskilled, and skilled workers - all blue-collar workers - have been favourite subjects of study by turnover researchers; clerical, sales, professional and managerial workers - all white-collar workers - have been studied less often. Since turnover refers to the movement of blue-collar and white-collar workers to many people, it is perhaps best to refer merely to "labour turnover" to promote a clearer understanding of the subject (Billups, 2002; Staw, 1980).

Moreover, voluntary and involuntary turnover are commonly distinguished. Voluntary turnover is individual movement across the membership boundary of a social system which is initiated by the individual (Akintayo, 2007). The term 'quit' is probably the most frequent label for voluntary turnover. 'Quit' and 'resignations' are generally used interchangeably. Involuntary turnover is movement not initiated by the individual examples of which are dismissals, layoffs, retirements, and deaths (Onimode, 1999).

Soyibo (2000) asserts that most involuntary turnover is probably initiated by the organization. Dismissal, layoffs, and retirements are examples of organizationally initiated turnover. It is possible, however, for turnover to be initiated by neither the member nor the organization. An example might be a wife, who leaves her job at her husband's insistence; the wife's turnover is initiated by her marriage partner. Involuntary turnover is best viewed as a residual concept that refers to all movement not initiated by the member. Although there are difficult methodological problems involved in distinguishing voluntary and involuntary turnover, the distinctions continues to dominate the literature (Price, 1992; Richard, 2004).

Even with the extensive amount of previous turnover research, relatively few strong generalizations are possible. The causes and correlates of employee turnover intention have been studied from many different perspectives. The economist may focus on the relationship between average wages and turnover rates by type of industry (Burton \& Parker, 2003 Armknecht \& Early, 1992). The human resource planner may look at turnover rates by occupational category, length of service etc. (Shadare, 2008). The sociologist may compare such variables as occupational groups, work group size, or communication pattern (Price, 1977). The industrial-organizational psychologist may study such individual determinants of turnover intention as job dissatisfaction (Hulin, 2002), commitment (Mowday, Steers, \& Porter, 1999), or behavioural intention to leave (Raut, 2005; Mobley, Horner, \& Hollingsworth, 2002).

The Brayfield and Crockelt (2005) analyses report reveal that for 2000 - 2002, the finance and health-care industries exhibited the highest total separation rates while manufacturing industries exhibited the lowest rates. Price (1977) classifies turnover rates by type of organization for 53 studies from 1947-1971. He found that manufacturing industries had the highest median separation rate and those goods producing organizations had over twice the separation rate of service producing organizations. A comparison of Price's conclusions and the more recent Brafield and Crockelt data is difficult because of differences in time period, criteria, and a sample composition.

Reviewers of the turnover literature report a consistent negative relation between age and tenure - younger employees have a higher probability of leaving (Muchinsky \& Tuttle 1979; Porter \& Steers, 1973; Price, 1977). The age turnover relationship may be based on a number of influences. Younger employees may have more entry-level job opportunities and few responsibilities, thus making job mobility easier. They may also have inaccurate expectations regarding working which are not fulfilled in their jobs (Porter \& Steers, 1973; Wanous 1980).

Similarly, the reviewers of the turnover literature report a consistent negative relationship between length of service and turnover. Turnover is significantly higher for shorter-tenure employees. Mangione (2003), in a national multivariate study, found that length of service is one of the best predictors of turnover intention. Hulin (2002) found that in any given cohort of hires, two-thirds to three-fourths of the quits will occur by the end of the first three years of service; of these, more than half will occur by the end of the first year alone.

Akintayo, (2003) in his study of workers' recruitment and retention found that turnover occurs at all levels of experience for a variety of reason, including family moves and child-rearing considerations. A national study reports that a little over a quarter of those who left their organizations leave because of a family move or because they need time for childbearing or child rearing (Ademoye, 1999). Besides, it was reported that ninety percent of the 
unmarried teachers, but only 45.8 percent of the married teachers, were still working (Marso \& Pigge, 1995). Lornu and Grissmer (1993) theories that the decision to accept and keep a job depends on life cycle factors such as existing family status and change in family status.

The literature reviewed for study revealed that various studies have been conducted on correlates of labour turnover which include marital status, length of service, relocation and life cycle (Ademoye, 1999; Marso \& Pigge, 1995, Lornu \& Grissmer, 1993 etc). However, little or no efforts have been directed towards job satisfaction, workfamily life, personal commitment to organizations and general health as they influence labour turnover in Nigeria. This existing gap serves as preoccupation for this study.

\section{Statement of Problem}

This study investigated the influence of personal factors on workers' turnover intention in South-West Nigeria. This is for the purpose of ascertaining the relevance of personal factors to turnover intention among workers in South-West Nigeria.

\section{Objectives of the Study}

The objectives of the study are to:

1. Determine the extent to which the personal factors (work- family life, job satisfaction, commitment to organization and general health) when combined together influence workers' turnover intention.

2. Find out the strength of causation of personal factors (job satisfaction, work family life, general health and personal commitment to organization) to influence workers' turnover intention.

3. Determine whether there is any significant difference between married and single workers' turnover intention on the basis of personal factors

4. Ascertain whether there is any significant difference between mal and female workers' turnover intention on the basis of personal factors

\section{Research Questions}

The following research questions were generated for this study:

1. To what extent will the personal factors (work family life, job satisfaction, commitment to organization and general health) combined together to influence workers' turnover intention?

2. What is the strength of causation of personal factors (job satisfactory, work family life, general health and commitment to organization) to influence workers' turnover intention?

3. Is there is any significant difference between married and single workers' turnover intention on the basis of personal factors

4. Is there is any significant difference between male and female workers' turnover intention on the basis of personal factors.

\section{METHODOLOGY}

\section{Research Design}

The methods of research utilized for this study were both qualitative and quantitative in nature. However, the descriptive survey method was adopted to examine the contribution of personal factors to workers turnover intention in work organizations in South-West Nigeria. The descriptive research method via the survey design enabled the researcher to collect data on the identified research problem without manipulating any of the variables of interest in the study. 


\section{Population}

The population for the study consists of all workers in the selected work organizations in South-West Nigeria. The population comprises of both male and female workers, who have spent at least two years in the selected work organizations.

\section{Sample and Sampling Technique}

Multi- stage sampling technique was used for sample selection. The simple random sampling method was utilized to select work organizations in South-West Nigeria. Thus, seven hundred and twenty five respondents were selected using proportional stratified sampling technique.

The respondents were selected from the strata of gender (male and female), marital status (married, single, separated, widow and divorced) and organizations (public and private) using stratified sampling method. Also, the proportional sampling method was adopted for selection of respondents on the basis of population of workers in each of the selected work organizations. The purposive sampling technique was used to select workers, who have spent at least two years in their respective organizations in South-West Nigeria.

\section{Instrument}

A set of self developed structured questionnaire titled "Personal and Organizational Factors of Teachers" Turnover Intention Scale “ (POFTTIS) was used for data collection. The questionnaire consists of five sections A, B, C, D, E and F. Section A focuses on demographic information about the respondents, such as, Name of organization, gender, age, marital status, educational qualifications, working experience etc.

Section B consists of six items relating to workers' intention to leave present employment. For example: 'You will leave your job at slightest opportunity'; 'You have already applied for alternative employment', 'You plan to look for a new job within the next 12 months', 'Thoughts about quitting your job cross your mind`etc. Section C focuses on job satisfaction and workers' turnover intention. For instance: 'My job is like hobby to me'; 'I am often bored with my job', 'I feel fairly well satisfied with my present job', 'I feel real enjoyments in my work' etc. Section D consists of items relating to work-family life. For instance; My official duties often conflict with my family life, I can join my spouse anytime from now, my spouse is encouraging me to quit my organization etc.

Section E focuses on general health and workers' turnover intention. For instance: Worker leaves your organization because of poor condition of health'; Delaying in implementing occupational health and safety policies often led to worker's turnover intention`, work- induced stress has led to increase in the rate of workers 'turnover intention` etc. Section F contained items relating to personal commitment to organization and workers' turnover intention. For example: Workers often found it difficult to identify with your organization; workers found it difficult to harmonize personal goal with organizational goal, workers usually protect their personal interest more often than of the organization etc.

\section{Validity of the Instrument}

The ability of the instrument to measure the variables it has been designed for was determined by the researcher. The researcher distributed 10 copies of the drafted questionnaire to experts in questionnaire construction for their suggestions and criticism. The experts' suggestions were incorporated into the final draft of the questionnaire, which led to modification of some items on the questionnaire.

\section{Reliability of the Instrument}

The consistency of the instrument in measuring the variables of interest in the study was determined using a pilot study. The researcher administered 50 copies of the questionnaire on respondents drawn from the University of Ibadan, Ibadan, which is outside the targeted population in South West Nigeria. The data collected through the pilot study was analyzed to determined reliability coefficient of the instrument using Kuber Cronbach coefficient 
alpha. Thus, Cronbach alpha of 0.84 was obtained for the instrument. In essence, the instrument is valid and reliable.

\section{Administration of the Instrument}

The researchers administered the measuring scales, which guarantee anonymity of the respondents, personally with the assistance of three trained research assistants. The researchers consulted with the Director of Personnel Administration in each of the selected private and public organizations in Nigeria, in order to intimate them with the purpose of the study. The researchers explained all aspects of the questionnaire to the respondents. However, through the help of the Directors of Personnel Administration, the researcher was able to administer the questionnaire with ease. However, it took the researchers a period of four weeks to administer and retrieve the distributed measuring scales due to geographical location of South-West Nigeria. 725 completely filled copies of the questionnaire were utilized for the purpose of the study.

\section{Method of Data Analysis}

The data collected through the questionnaire was analyzed using percentage and frequency counts for demographic information about the respondents. However, hypothesized research questions one and two were tested using Regression Analysis. Hypothesized research questions three and four were tested with the use of t-test statistical method. All the four hypothesized research questions were tested at 0.05 alpha levels.

\section{RESULTS}

This section focuses on presentation of results and discussion of findings. The results of the analyzed data were interpreted on the basis of the research questions generated for the study.

\section{Research question 1}

To what extent will the personal factors (work family life, job satisfaction, commitment to organization and general health) combined together to influence teachers' turnover intention.

Table 1: Summary of Regression Analysis of Personal Factors as Predictors of Workers' Turnover Intention

\begin{tabular}{|c|c|c|c|c|c|c|}
\hline \multicolumn{7}{|c|}{$\begin{array}{l}\mathrm{R}=0.584 \\
\mathrm{R} \text { square }=0.375 \\
\text { Adjusted } \mathrm{R} \text { square }=0.339 \\
\text { Standard error }=8.702\end{array}$} \\
\hline & Sum of square & Df & Mean square & $\mathbf{F}$ & Sig & Remark \\
\hline $\begin{array}{l}\text { Regression } \\
\text { Residual } \\
\text { Total }\end{array}$ & $\begin{array}{c}64532.521 \\
10336.76 \\
74868.597\end{array}$ & $\begin{array}{c}4 \\
720 \\
724\end{array}$ & $\begin{array}{c}34251.782 \\
98.657\end{array}$ & 121.570 & $000^{\mathrm{a}}$ & $*$ \\
\hline
\end{tabular}

* Significant $(\mathrm{P}<0.05)$.

In table 1 above, the finding of the study indicated that all the personal factors (work family life, job satisfaction personal commitment to organization and general health) account for $37.5 \%$ of the total variance in teachers' turnover intention. This percentage is statistically significant $\left(\mathrm{R}^{2}=0.375 ; \mathrm{P}<0.05\right)$. Thus, all the personal factors are very important in predicting teachers' turnover intention. It implies that individual employees' intention to change their job may be personal, not necessarily organizational.

\section{Research question 2}

What is the strength of causation of personal factors (job satisfactory, work family life, general health and commitment to organization) to influence workers' turnover intention. 
Table 2: Summary of Regression Analysis of Strength of Causation of Personal Factors on Workers' Turnover Intention

\begin{tabular}{|l|c|c|c|c|c|c|}
\hline \multicolumn{1}{|c|}{ Model } & \multicolumn{2}{|c|}{$\begin{array}{c}\text { Unstandardized } \\
\text { coefficients }\end{array}$} & $\begin{array}{c}\text { Standardized } \\
\text { coefficients }\end{array}$ & & Remark \\
\hline & B & Std Error & Beta & t & Sig & \\
\hline 1 (constant) & 17.328 & 1.326 & & -11.231 & .000 & $*$ \\
& & & & & & \\
- Job satisfactory & .256 & .041 & .345 & -5.457 & .001 & $*$ \\
- Work family life & .275 & .045 & .205 & 9.713 & .000 & $*$ \\
- General health & .943 & .054 & .213 & 17.624 & .000 & $*$ \\
- Commitment to & .267 & .054 & .145 & 7.489 & .000 & $*$ \\
Organization & & & & & & \\
\hline
\end{tabular}

$\mathrm{NS}=$ Not significant $(\mathrm{P}>0.05)$

* = Significant $(\mathrm{P}<0.05)$

In the table 2 above, the findings revealed that all the personal factors are considered. In this table, four personal factors: job satisfactory, work-family life, general health and commitment to organization. All these eight independent variables have significant causal influence on workers' turnover intention. The order of causation in descending order of magnitude is: Job satisfaction (Beta $=0.345, \mathrm{P}<0.05)$; work-family life (Beta $=0.205 ; \mathrm{P}<0.05)$, general health $($ Beta $=0.213 ; \mathrm{P}<0.05)$, and personal commitment to organization $($ Beta $=0.145 ; \mathrm{P}<0.05)$. Job satisfaction is the greatest factor that makes employees to intend leaving an organization and the least significant factors is commitment to organization.

\section{Research Question 3}

Is there any significant difference between single and married workers' turnover intention?

Table 3: Summary of t-test Analysis of Marital Status and Workers' Turnover Intention on the Basis of personal factors

\begin{tabular}{|c|c|c|c|c|c|c|c|c|}
\hline & $\mathbf{N}$ & Mean & $\begin{array}{c}\text { Std } \\
\text { Dev. }\end{array}$ & $\begin{array}{c}\text { Std } \\
\text { Error }\end{array}$ & Df & $\mathbf{T}$ & $\mathbf{P}$ & Remark \\
\hline Married & 412 & 18.231 & 12.435 & 0.238 & \multirow[b]{2}{*}{723} & \multirow[b]{2}{*}{3.428} & \multirow[b]{2}{*}{0.321} & \multirow[b]{2}{*}{ NS } \\
\hline Single & 313 & 17.453 & 10.254 & 0.389 & & & & \\
\hline
\end{tabular}

NS = Not significant $(\mathrm{P}>0.05)$

In table 3 above, the finding showed that there is no significant difference between single and married teachers' turnover intention $(\mathrm{t}=3.428, \mathrm{P}>0.05)$. The finding implies that both single and married workers have equal level of intention to stay or leave organizations.

\section{Research Question 4}

Is there any significant difference between male and female workers' turnover intention on the basis of personal factors?

Table 4: Summary of t-test Analysis of Comparison of Male and Female Workers`Turnover Intention on the Basis of

\begin{tabular}{|l|c|c|c|c|c|c|c|c|}
\hline & N & Mean & $\begin{array}{c}\text { Std } \\
\text { Dev. }\end{array}$ & $\begin{array}{c}\text { Std } \\
\text { Error }\end{array}$ & Df & t & P & Remark \\
\cline { 1 - 6 } Male & 468 & 18.427 & 10.324 & 0.342 & \multirow{2}{*}{723} & 4.654 & 0.000 & $*$ \\
\hline Female & 257 & 16.546 & 8.672 & 0.267 & 723 & $*$ \\
\hline
\end{tabular}

* Significant $(\mathrm{P}<0.05)$

As indicated in table 4, the finding revealed that there is a significant difference between male and female workers' turnover intention $(\mathrm{t}=4.654, \mathrm{P}<0.05)$. Male workers have greater tendency to leave their jobs than their female counterparts. 


\section{DISCUSSION OF FINDINGS} Nigeria.

This study investigated the influence of personal factors on workers` turnover intention in South-West

The findings of the study revealed that all the personal factors (work family life, job satisfaction, commitment to organization and general health) taken together predict workers' turnover intention. Thus, all the personal factors are very important in predicting workers' turnover intention. It implies that individual workers` intention to change their jobs may be personal, not necessarily organizational. As stated earlier, job satisfaction refers to an employee's positive appraisal of their work situation (Ademoye, 1999; Adewoyin, 2002). The underpinning premise is that employees who are satisfied with their jobs are less likely to have turnover intentions.

Moreover, in line with the findings of the study, Hulin (2002) and Derek (2006) submitted that commitment refers to an employee's attitude, expresses their emotional bond and uniqueness with the organization The present study predicted that workers, who are more committed to the organization would be less likely to have turnover intentions. This rationale was based on the assumption that if an employee's commitment is affective he or she will stay "with the organization because they want to". An explanation of why this hypothesis was supported can be seen when looking through the lens of psychological attachment. When the employees have a sense of psychological attachment to an organization, they can identify with the organization's policies, goals and values and feel adherence and devotion to the organization (Richard, 2004). This implies that employees are prepared to stay with organization based on their psychological attachment, rather than a continuance based on a calculative exchange (Adewoyin, 2002, Akintayo, 2003 ; Derek, 2006).

Meanwhile, the findings of the study disagreed with Soyibo (2000) and Billups, (2002) who reported that satisfaction and commitment were not correlated with turnover intentions since normative commitment was a driving force. This implies that the longer the employee stays with the organization, gaining transferable skills and valuable experience, the more he/she is inclined to remain with the organization.

The finding of this study disagreed with Derek (2006); Onimode (1999), Akintayo (2007), who posited that work-to-family conflict, did not correlate with turnover intentions among the health workers. This was based on the premise that health practitioners have perceptions that their employed organization, Waikato District Health Board, is work-family friendly and provides work-family benefits. Paton, Jackson and Johnston (2003) found that in organizations that provide an inclusive work family culture and have policies and procedures that are conducive to work and family, therefore the employees experience less incidences of work-family conflict.

Besides, the finding showed that there is no significant difference between single and married workers' turnover intention. The finding implies that both single and married workers have equal level of intention to stay or leave their organizations. The finding agreed with Derek (2006); Mangione (2003), Soyibo (2002), Brayfield and Crockelt (2005) who reported that turnover intention does not correlate with marital status of the workers. Meanwhile, the finding is contrary to finding of Richard (2004) who reported that married workers tend to desire to quit an organization due to spouse relationship and location that could require relocation of the workers.

Moreover, the finding revealed that there is a significant difference between male and female workers turnover intention. Male workers have greater tendency to leave their jobs than their female counterparts. To corroborate this finding, Panes (2001) and Hulin (2002) reported that the incidences of turnover intention were more predominant for women than men, possibly due to work-family role conflict.

A cursory look at the finding of the study revealed that the general health of the worker tends to influence their turnover intention. This finding tally with the views of O'Driscoll and Brough (2003) who asserted that one approach into health and well-being in the workplace was the stress or strain relationship that explains the influence of job demands on employees' intention to quit or stay with an organization. A second approach is looking at enhancing employees' health and well-being through positive experiences in the form of variety and autonomy, leading to greater job satisfaction and performance. Occupational strain needs to be dealt with not only for the benefit of the individual, but also for the organization as a whole. Increasing strain produces anxiety that ultimately 
affects personal health, morale, productivity, organizational efficiency leading to absenteeism, job dissatisfaction, decreased organizational commitment, and voluntary turnover (Allen \& Meyer, 1996; Akintayo, 2007).

In contrast, the employee with strong economical/calculative ties to the organization (continuance commitment) will stay because of the 'side bets' they have invested in the organization. The side bets can be monetary value, a pension plan, specific skills acquired whilst working there or status (Allen \& Meyer, 1996 ; Onimode, 1999) and would be lost if he/she decides to leave. It is expected that both affective and continuance commitment will be negatively associated to turnover intentions (Raut, 2005; Hulin, 2002).

\section{CONCLUSION}

The findings of the study submitted that personal factors have significantly contributed to workers turnover intentions. The findings also established that the personal factors such as, job satisfaction, work-family life, general health and commitment to organization combined together to influence workers' turnover intention. Therefore, organizations need to focus on how to foster job satisfaction, conflict free work-family life, and improved general health, commitment to organization in order to attract and retained competent workers. These findings indicate that organizations in Nigeria can take positive actions that would facilitate employee retention. The findings of this study provide information that will be useful to organizations, personnel psychologist and researchers, behavioural scientists, and management practitioners.

\section{RECOMMENDATIONS}

Based on the findings of the study, it was recommended that:

1. Leavers often cite "lack of job satisfaction" as a reason for resignation. However, a number of elements cluster around what is broadly known as job satisfaction, and can often be linked with aspects of job design and contents. Government and employers at all levels should endeavour to improve workers` level of job satisfaction in order to induce the workers to stay longer in the organization.

2. However, for retention of workers to be made possible, motivational incentives that could foster workers job satisfaction should be provided at equitable measure of reward in terms of wages and salaries to be made commensurate with workers` job performance. (3) Also, organizational support system that could promote workers`good health and reduction of occupational hazards should be provided for all levels of workers in order to guarantee workers` retention.

\section{AUTHOR INFORMATION}

Dr Elsie Omolara Babajide was born in 1966 in Nigeria. Her Primary, secondary and tertiary education was also in Nigeria. She is a specialist in Industrial Education where she possessed a Masters as well as a PhD degree. She has taught in reputable universities in Nigeria for ten years. She has published articles in local as well as international journals. She has also attended both local and international conferences where she has presented scholarly articles. Her special area of interest has been in Management as well as leadership studies. She is beautifully married and has lovely children.

\section{REFERENCES}

1. $\quad$ Ademoye, M.O (1999). Child, rearing \& child bearing. Lagos: University Press.

2. Adewoyin, F.A. (2002). Labour turnover and organizational goal achievement in selected industries in Oyo State. Unpublished Ph.D. Thesis, University of Ibadan, Ibadan.

3. Allen, N. J., and Meyer, J.P. (1996). Affective, continuance, and normative commitment to the organization: An examination of construct validity. Journal of Vocational Behavior, 49, 252-276.

4. Akintayo, D.I. (2007). Impact of labour turnover on organizational effectiveness in selected industries in Lagos State, Nigeria. Journal of Institute of Educational Planning and Administration (Ghana. 8(2), 58-67.

5. Akintayo, D.I. (2003). Analysis of correlates of labour turnover behaviours in work organization: Journal of Industrial Education, 4, (2), 46-54. 
6. Armknecht, P.A. and Early: (1992). Quit in manufacturing industries. A study of their causes. Monthly Labour Review, 95:31-37.

7. Billups K.A. (2002). A meta analysis of why workers remain in organizations. Harvard Review, 46, 19-27.

8. Brayfield, A.H. and Crockelt, W.H (2005). Employee attitude and employee performance. Psychological Bulletin, 52, 396-424.

9. Burton J.F. and Parker J.E. (2003). Inter industry variation in voluntary labour mobility. Industrial Labour Relations Review, 22, 199-216

10. Derek, R. (2006). Turnover intentions: The mediation effects of job satisfaction, affective commitment and continuance commitment. Unpublished Masters Thesis, University of Waikato.

11. Hulin, C.L. (2002). Effects of changes in job satisfaction levels on employee turnover. Journal of Applied Psychology, 52:122-126.

12. Lornu, D.L. and Grissmer, P.M. (1993). Workers' decision to quit: Whose fault . Journal of Occupational Psychology, 21 (2), 41-52

13. Magione, W. (2003). Turnover: Some psychology and demographic correlates. The 1969-1970 survey of working conditions (eds.) Robert P. Quim and Thomas, W. Mangione. Ann Abbor: Final report to employment standard admin., U.S. Dept. Labour, survey research center, University of Mich.

14. Marso, R. \& Pigge, F. (1995). Characteristics associated with teacher attrition: Pre-and post-preparation teaching concerns of candidates teaching or not teaching five years after graduation. Paper Presented at the Aannual Meeting of the Midwestern Educational Research held at Chicago, Illinois.

15. Mobley, W. H. Horner, S. O. \& Hollingworth, A. T. (2002). An evaluation of precursors of hospital employee turnover. Journal of Applied Psychology, 63, 408-414.

16. Mowday, R. T., Porter, L. W. Steers, R. M. (1999). When employees feel betrayed: A model of how psychological contract violation develops. Academy of Management Review, 22, 226-256.

17. Muchinsky, P. M. Tuttle, M. L. (1979). Employee turnover: An empirical and methodological assessment. Journal of Vocational Behaviour, 14, 43-77.

18. Onimode, B. (1999). The effects of labour turnover on individual organization and society, Paper Presented at the $34^{\text {th }}$ Annual Meeting of the Academy of Management, Seattle.

19. O'Driscoll, M. P. \& Brough P. (2003). Job stress and burnout. In M. O'Driscoll, P. Taylor, \& T Kalliath (Eds.). Organizational psychology in Australia and New Zealand (p 188-211). Melbourne, Australia: Oxford University Press.

20. Panes, A.C. (2001). Is all well with teachers in public school? Journal of Educational Research, 21 (1), 88 $-96$.

21. Paton, I.C. Jackson, Y.O. and Johnson, E.T. (2003). Organizational, work and personnel factors in employee turnover and absenteeism. Psychological Bulletin, 80,151-176.

22. Porter, L. W. Steers, R. M. (1973). Organizational commitment, job satisfaction and turnover among psychiatric technicians. Journal of Applied Psychology, 59:603-609.

23. Price, J.L. (1992). A Handbook of organizational measurement. Lexington: D.C. Health.

24. Price, J.L. (1977). The study of turnover. Ames, Iowa: Iowa State University Press.

25. Raut, R.S. (2005). Organizational leadership: Theory and practice. New York. Johnhalt House.

26. Richard, D.O. (2004). Investigation of teachers' behaviour in schools. Journal of Social Studies and Development. 23, 98-112.

27. Shadare, D.A. (2008). Labour turnover and organizational effectiveness: moderating effects of job classification, career mobility and job complexity. Journal of Management, 9 (2), 77-86.

28. Soyibo, S.A. (2002). Ecological correlations and labour turnover, American Sociological Review. 15:341347.

29. Soyibo, S.A. (2000). Economic factors in worker turnover behaviour. Journal of Economic and Development, 16 (2), 71-83.

30. Staw, B.M. (1980). The consequences of turnover. Journal of Occupational Behaviour, (1) 253-273.

31. Steers, R.M. and Mowday, R.T. (1981). Employment turnover and post decision accommodation process. In B.M. Shaw and L.L. Cummings (Eds) Research in organizational Behaviour. London: Prentice Hall.

32. Wanous, J. P. (1980). Organization entry: Recruitment, selection and socialization of newcomers. Reading mass: Addison - Wesley. 


\section{NOTES}

